\title{
TINJAUAN HUKUM ISLAM TERHADAP AKAD HYPNOTHERAPY
}

\author{
Nabella Dananier \\ Institut Agama Islam (IAI) Ngawi \\ Email: nabelladananierwijaya@gmail.com \\ Yusron Wijaya \\ Institut Agama Islam Ngawi \\ Email: yusronwijaya@gmail.com
}

\begin{abstract}
Islamic law is basically a universal law that can be applied without being constrained by time. The elasticity of Islamic law provides answers to every phenomenon that arises so that Islamic law will always be relevant to be applied anytime and anywhere and there is no doubt that Islamic law is eternal. Lately there are many alternative treatments commonly called hypnotherapy. Hypnotherapy is a method of treatment using hypnotic patterns. Hypnotherapy in its development continues to undergo modifications from its practitioners, because each hypnotherapist has values that make it unique. The review of Islamic law on hypnotherapy contracts aims to find out the truth about the practice of hypnotherapy, especially in the PPT Counseling and Psychotherapy Clinic in Yogyakarta. In this study using qualitative methods with data collection through interviews and documentation. The primary informants in the study were hypnotherapists and clients who had undergone hypnotherapy. The data obtained is then analyzed by relating it to Islamic law. The application of the contract in hypnotherapy at the PPT Counseling and Psychotherapy Clinic in the Yogyakarta area does not violate sharia principles. This is because the contract that occurs in hypnotherapy is fulfilled properly. In addition, there is no element of coercion at all, because the hypnotherapy they undergo requires a voluntary state from the client to facilitate the hypnotherapy process.
\end{abstract}

Keywords: Islamic Law, Hypnotherapy.

\section{A. Pendahuluan}

Pada kehidupan yang serba modern ini, banyak ditemukan transaksi kontemporer yang memerlukan penilaian hukum figh-nya. Sebagai sistem kehidupan, Islam memberikan warna dalam setiap dimensi kehidupan tak terkecuali dibidang bisnis. Islam datang memberikan dasar-dasar dan prinsip-prinsip yang mengatur secara baik terhadap persoalan-persoalan muamalat tersebut. Berkaitan akan hal itu, belakangan ini terdapat sebuah metode penyembuhan dengan memanfaatkan alam bawah sadar manusia 
yaitu hipnoterapi. Hipnoterapi yang sebelumnya merupakan sebuah fenomena asing, kini mulai dapat diterima kehadirannya. Terbukti dengan semakin banyaknya tawaran seminar-seminar ataupun pelatihan-pelatihan yang bertemakan hipnoterapi. Kemudian klinik-klinik pengobatan menggunakan hipnoterapi juga banyak bermunculan. Contohnya saja seperti yang ada di Rumah Sakit Umum Daerah Salatiga. Klinik hipnoterapi yang mulai beroperasi pada 2010 tersebut bertujuan untuk menghilangkan kecanduan, penyakit ketakutan (phobia), alergi, manajemen rasa sakit, dan penyakit medis lainnya. Hipnoterapi juga akan mulai diterapkan di beberapa bagian di RSUD, termasuk di instalasi gawat darurat (IGD).

Tentu, kehadiran dari metode penyembuhan ini tidak serta merta dapat diterima secara otomatis oleh kebanyakan orang, terutama muslim sebagai komunitas besar di Indonesia. Karena, sebagian orang menganggap hipnoterapi itu tidak berbeda jauh dengan sihir seperti gendam, yang kemudian mencitrakan hal itu negatif. Citra negatif dari sebagian kalangan itu tak lain karena maraknya kejahatan dengan menggunakan ilmu hipnosis. Praktisi hipnoterapi Mardigu Wowiek Prasantyo mengatakan "Hipnotis dan Gendam itu berbeda. Namun, efeknya sama. Efeknya disebut transhipnosis, yaitu perasaan setengah sadar yang tidak bisa dikendalikan". ${ }^{85}$ Selama ini juga masyarakat membayangkan seseorang dengan kemampuan hipnosis dianggap bisa melakukan apapun kepada subjeknya, termasuk seperti hipnotis yang ada di TV. Padahal, itu belum tentu benar semua, karena di negara-negara maju hipnosis berkembang pesat dan dimanfaatkan secara positif. Bahkan di beberapa universitas di Amerika Serikat, hipnosis dipelajari hingga tingkat doktoral. ${ }^{86}$

Meskipun begitu, kontroversi mengenai hipnoterapi pun masih terus bergulir. Permasalahan yang sering naik ke permukaan masih saja berkutat pada dugaan bantuan jin atau sejenisnya. Ketika terdapat unsur demikian tentu hal tersebut bertentangan dengan syariat Islam. Hal demikian tentu lebih berbahaya dari pada sekedar citraan negatif, karena dampaknya bisa menjerumuskan seseorang ke dalam ladang kemusyrikan (menyekutukan Allah swt). Namun, tidak boleh pula dipungkiri bahwa pada dasarnya hipnosis atau dalam hal ini hipnoterapi merupakan ilmu yang sifatnya netral, di mana semua tergantung pada niat dan cara yang dilakukan.

Hipnoterapi dalam perkembangannya pun terus mengalami modifikasi dari para praktisinya, karena setiap hipnoterapis memiliki value yang menjadikan ciri khas tersendiri. Terlebih, kegiatan tersebut menjadi lahan

${ }^{85}$ Natalia Ririh, "Ini Hipnotis atau Gendam?", http://health.kompas.com/read/2010/08/27 /14375388/Ini.Hipnotis.atau.Gendam, akses 16 November 2020.

86 Ibnu Hajar, Hypnoteaching, (Yogyakarta: Diva Press, 2011), h. 12. 
bisnis bagi para penggiatnya. Dengan memberikan jasa terapi menggunakan hipnosis, para hipnoterapis pun mendapatkan fee sesuai ketentuan yang berlaku pada masing-masing penyelenggara. Begitu pula yang terdapat pada Klinik Konseling dan Psikoterapi PPT ${ }^{87}$ khususnya di wilayah Yogyakarta. Hipnoterapi pada klinik tersebut merupakan salah satu metode yang digunakan untuk sekian banyak jasa layanan atau produk yang ditawarkan. Jadi, hipnoterapi mendominasi terhadap kebanyakan pelayanan jasanya.

Bermula dari latar belakang yang dipaparkan sebelumnya, penulis tertarik untuk mengkaji lebih jauh kegiatan tersebut, mengingat jasa yang diberikan berupa hal yang tidak terlihat yaitu mengolah kesadaran. Selain itu juga karena terdapat keanekaragaman prosedur yang dilakukan antara klinik yang satu (termasuk juga praktisi hipnoterapi) dengan lainnya.

\section{Metodologi Penelitian}

Penelitian ini menggunakan jenis penelitian lapangan (field research), yaitu penelitian dan pengumpulan data yang dilakukan secara langsung di lapangan penelitian guna memperoleh data tentang pelaksanaan hipnoterapi di PPT wilayah Yogyakarta. 88 Adapun pendekatan penelitian menggunakan pendekatan kualitatif, yang memiliki karakteristik alami (natural setting) sebagai sumber data langsung, deskriptif, proses lebih dipentingkan dari pada hasil, analisis dalam penelitian kualitatif cenderung dilakukan secara analisa induktif dan makna merupakan hal yang esensial. ${ }^{89}$

Teknik Pengumpulan Data yang digunakan dalam penelitian ini melalui; 1) Wawancara, Wawancara yang digunakan peneliti adalah wawancara tidak terstruktur atau wawancara bebas dimana peniliti tidak menggunakan pedoman wawancara yang tersusun secara sistematis dan lengkap untuk pengumpulan datanya. Pedoman wawancara yang digunakan hanya berupa garis-garis besar permasalahan yang akan ditanyakan.90 Tujuan penggunaan metode ini agar peneliti mendapatkan informasi lebih mendalam mengenai praktek hipnoterapi.; 2) Dokumentasi merupakan setiap bahan tertulis baik berupa karangan, memo, pengumuman, instruksi, majalah, buletin, pernyataan, surat-surat, catatan harian, cindera mata, laporan dan lain-lain yang sifatnya tidak terbatas ruang dan waktu sehingga

87 PPT merupakan singkatan dari Pusat Psikologi Terapan.

88 M. Kholis Amrullah and M. Irfan Islamy, Perencanaan Penelitian: Perjalanan Sistematis Penemuan Teori, ed. Ani Cahyadi (Malang: CV. Literasi Nusantara Abadi, 2020), h. 32.

${ }^{89}$ Pendekatan kualitatif adalah prosedur penelitian yang menghasilkan data deskriptif berupa kata-kata tertulis atau lisan dari orang-orang dan perilaku yang dapat dialami. Lihat dalam Lexy Moleong. Metodologi Penelitian Kualitatif (Bandung: PT. Remaja Rosda Karya, 2002), h. 3.

90 Sugiyono, Metode Penelitian Bisnis, (Bandung: Alfabeta CV, 2007), h. 132. 
memberi peluang kepada peneliti untuk mengetahui hal-hal yang pernah terjadi di waktu silam. ${ }^{91}$ Tujuan digunakan metode ini untuk memperoleh data secara jelas dan konkret tentang akad dalam hipnoterapi.

Analisis data adalah proses mengorganisasikan dan mengurutkan data kedalam pola, kategori, dan satuan uraian dasar sehingga dapat ditemukan tema dan dapat dirumuskan hipotesis kerja seperti yang disarankan oleh data. Dari rumusan di atas dapatlah kita tarik garis besar bahwa analisis data bermaksud pertama-tama mengorganisasikan data. Data yang terkumpulterdiri dari catatan lapangan, komentar peneliti, gambar, foto, dokumen berupa laporan, biografi, artikel, dan sebagainya. Setelah data dari lapangan terkumpul dengan menggunakan metode pengumpulan data di atas, maka peneliti akan mengolah dan menganalisis data tersebut dengan menggunakan analisis secara deskriptif-kualitatif, tanpa menggunakan teknik kuantitatif. Analisis deskriptif-kualitatif merupakan suatu teknik yang menggambarkan dan menginterpretasikan arti data-data yang telah terkumpul dengan memberikan perhatian dan merekam sebanyak mungkin aspek situasi yang diteliti pada saat itu, sehingga memperoleh gambaran secara umum dan menyeluruh tentang keadaan sebenarnya.

\section{B. Pembahasan}

\section{Analisis Hukum Islam Terhadap Praktek Hipnoterapi}

Pada dasarnya Islam membolehkan pekerjaan apapun, akan tetapi tetap terdapat batasan berupa prinsip-prinsip yang harus diperhatikan dalam bekerja, seperti prinsip keseimbangan hidup, keikhlasan, halal dan haram. Semua prinsip itu harus ada dikarenakan terkadang hal-hal tersebut dianggap sepele sehingga melanggar ketentuan Islam. Kriteria pekerjaan yang bisa dikategorikan halal dalam Islam, yaitu ketika:92

1. Suatu pekerjaan yang tidak mengandung unsur seks di dalamnya, misal pelacuran, bisnis diskotik, rumah bordir, dan lain semacamnya.

2. Suatu pekerjaan yang tidak memproduksi barang-barang haram, misalnya produksi minuman keras, narkotika, dan semacamnya.

3. Suatu pekerjaan tidak mengandung unsur pemeliharaan hewan atau binatang haram, misalnya ternak babi dan sejenisnya.

${ }_{91}$ Burhan Bungin, Penelitian Kualitatif, (Jakarta: Kencana Prenada Media Group, 2008), h. 122.

92 Azam Syukur Rachmatulloh, "Praktek Kerja dan Pengupahan Jasa Perawatan Tubuh Oleh Kaum Gay dalam Perspektif Hukum Islam pada Salon Kecantikan Bagus di Godean Jogjakarta", skripsi tidak diterbitkan, Fakultas Syari' ah IAIN Sunan Kalijaga Yogyakarta (2003), h. 15. 
Hukum Islam diterapkan tanpa terkekang masa karena mampu menyikapi setiap perubahan yang terjadi, baik dalam masalah sosial ekonomi, budaya dan politik. Elastisitas hukum Islam memberikan jawaban pada setiap fenomena yang muncul sehingga hukum Islam akan selalu relevan untuk diterapkan kapan dan dimana saja dan tidak diragukan lagi bahwa hukum Islam bersifat abadi. Hukum ada untuk menjawab semua permasalahan dan ditegakkan demi keadilan. ${ }^{93}$

Mengikuti alur proses hipnoterapi yang terjadi, terlihat bahwasannya hipnoterapi yang dijalankan khususnya PPT pada wilayah Yogyakarta sama sekali tidak mengandung unsur-unsur yang dilarang tersebut, termasuk juga tidak ada mistik atau bantuan makhluk gaib. Kemampuan sugestibilitas hipnoterapis-lah yang menjadi kekuatannya. Hipnoterapis menggunakan keterampilannya dalam memanfaatkan penekanan terhadap kata-kata yang diucapkan. Selain itu, pola persuasif yang dilakukan bisa membangkitkan motivasi positif yang ada dalam diri klien. Sehingga dapat ditarik benang merahnya, bahwa hipnoterapi bukan merupakan praktek kerja yang dilarang oleh hukum Islam.

\section{Analisis Hukum Islam dalam Akad Hipnoterapi}

Akad dalam hukum Islam merupakan perjanjian dan persetujuan diantara dua orang secara legal, berpengaruh, dan juga bersifat mengikat. ${ }^{94}$ Kepentingan dari pada akad itu sendiri adalah terjalinnya suatu ikatan kesepakatan dalam sebuah transaksi agar sebuah permasalahan tidak timbul dikemudian hari.

Suatu akad yang sah dan mengikat, haruslah dipenuhi rukun dan syarat akadnya. Adapun rukun dan syarat sahnya sebuah akad adalah sebagai berikut;

\section{Para Pihak}

Sebagai rukun pertama dari pada akad, terdapat dua syarat yang mendampinginya, yaitu:

a. Memiliki tingkat kecakapan hukum

Kecakapan hukum (al-ahliyyah) didefinisikan sebagai kelayakan seseorang untuk menerima hukum atau bertindak hukum, atau sebagai "kelayakan seseorang untuk menerima hak dan kewajiban dan untuk diakui tindakan-tindakannya secara hukum syariah" ${ }^{95}$

\footnotetext{
93 Ahmad Azhar Basyir, Qa'idah-qa'idah Fiqih (Qawa'idul Fiqhiyah), (Jakarta: Bulan Bintang, 1976), h. 141.

94 Veithzal Rivai dkk., Islamic Transaction Law in Business: dari Teori ke Praktik, (Jakarta: Bumi Aksara, 2011), h. 6.

95 Wahbah az-Zuhaili, al-Figh al-Islami wa Adillatuh, cet. ke-3 (Damaskus:Dar al-Fikr, 1989), h. 116.
} 
Pada pelaksanaan syarat akad dari rukun pertama tersebut, klien yang datang untuk hipnoterapi semuanya adalah yang berada pada tingkat kecakapan menerima hukum sempurna (ahliyyatul-wujub alkamilah). Hal itu dikarenakan secara lahiriyah klien bisa menerima konsekuensi dari keputusannya yang sukarela untuk dihipnoterapi demi kesembuhan yang diharapkan.

Untuk kecakapan bertindak hukum (kecakapan hukum aktif), yang dalam istilah hukum Islam disebut ahliyyatul-ada', terlihat bahwasannya ketika menghadapi klien yang sejatinya adalah anak yang berada dibawah usia tamyiz, maka yang melakukan akad atau kesepakatan awal untuk dihipnoterapi adalah orang tua/ wali dari klien karena termasuk kecakapan bertindak hukum tidak sempurna yang butuh ratifikasi (pengesahan) dari orang yang sudah dapat bertindak hukum secara sempurna. Sehingga, tingkat kecakapan hukum yang dimaksudkan dalam persyaratan melakukan akad terpenuhi secara jelas.

b. Berbilang pihak

Karena akad merupakan pertemuan antara ijab dari salah satu pihak dan kabul dari pihak lain, maka perjanjian (akad) akan tercipata jika terdapat lebih dari satu pihak (berbilang pihak). Dalam berakad, seseorang diperbolehkan untuk dapat diwakilkan atau memberikan kuasa terhadap orang lain guna membuat perjanjian (akad) atas namanya. Begitu pula seseorang dapat menjadi wakil atau kuasa bagi orang lain dalam penutupan suatu perjanjian.

Syarat berbilang pihak dalam akad hipnoterapi sudah pasti ada karena terdapat klien dan hipnoterapis yang mengadakan kesepakatan. Selain itu, untuk klien yang belum tamyiz maka kesepakatan yang terjadi adalah antara orang tua/ wali dari klien dengan hipnoterapis.

2. Pernyataan Kehendak

Shigatul-'aqd, merupakan rukun kedua dari akad yang terdiri atas ijab dan kabul. ${ }^{96}$ Ijab dan kabul sendiri merupakan representasi dari perizinan (ridha, persetujuan). Dalam rukun kedua akad ini terdapat dua syarat, yaitu (1) adanya persesuaian ijab dan kabul yang menandai adanya persesuaian kehendak sehingga terwujud kata sepakat, dan (2) persesuaian kehendak (kata sepakat) itu dicapai dalam satu majelis yang sama, dengan kata lain syarat kedua ini adalah adanya kesatuan majelis akad. ${ }^{97}$

96 Urutan rukun akad berbeda-beda dari satu kitab ke kitab lain. Akan tetapi semuanya sepakat menyatakan pernyataan kehendak (shigatul-'aqd) yang terdiri dari ijab dan kabul sebagai rukun akad, bahkan rukun satu-satunya dalam mazhab Hanafi.

${ }^{77}$ Syamsul Anwar, Hukum Perjanjian Syariah: Studi tentang Teori Akad dalam Fikih Muamalat, (Jakarta: PT Raja Grafindo Persada, 2010), h. 122. 
Pada rukun kedua dalam akad ini terlihat ketika sebelum hipnoterapi dimulai, yaitu pernyataan dari klien untuk melanjutkan hipnoterapi atau tidak secara lisan setelah mendapatkan informasi mengenai apa saja yang akan dilakukan dalam hipnoterapi. Pernyataan tersebut menandakan bahwa hipnoterapis menawarkan (ijab) kepada klien untuk mempertimbangkan penjelasan yang diberikan sebelumnya. Dalam pandangan hukum perjanjian Islam pernyataan kehendak yang paling penting melalui pengetahuan kita terhadap kehendak sejati dari ucapan seseorang karena inilah yang paling banyak terjadi. Ucapan dapat terjadi dalam akad antara pihak-pihak yang saling berhadapan langsung.

\section{Objek Akad}

Rukun ketiga dari akad menurut hukum perjanjian Islam adalah adanya objek akad. Apabila tidak adanya objek akad, tentu akadnya akan sia-sia. Karena prestasi tidak dapat dituntaskan jika objeknya saja tidak ada. Apabila objek akad berupa suatu perbuatan seperti mengajar, melukis, mengerjakan suatu pekerjaan, maka pekerjaan itu harus mungkin dapat dilaksanakan. Sebagaimana terdapat dalam hadits Abu Hurairah:

$$
\text { عن أبي هريرة قل نهى رسول الله صلّى الله عليه وسلّم عن بيع الحصاة وعن بيع الغرر. }
$$

Hadits di atas melarang jual-beli terhadap barang yang tidak dapat dipastikan bisa diserahkan atau tidak. Jadi, aturan umum bahwa objek tersebut harus merupakan barang yang dapat dipastikan dapat diserahkan. Namun, ketika dihadapkan pada objek akad yang berupa suatu perbuatan seperti mengajar, melukis, mengerjakan suatu pekerjaan, maka sebagaimana disebutkan sebelumnya memiliki syarat perbuatan atau pekerjaan tersebut mungkin dilaksanakan. Tidak boleh merupakan hal yang tidak dapat dipastikan bisa atau tidak dapat dilaksanakan, karena jika demikian dalam objek ini terdapat gharar yang dilarang dalam hadits Nabi Saw. Objek tersebut juga harus dijelaskan sejelas-jelasnya sehingga menghindari ketidakjelasan yang mencolok. Jika terdapat ketidakjelasan pekerjaan maka akadnya menjadi fasid. ${ }^{99}$

Selain itu objek akad dapat ditransaksikan menurut syarak dan tidak menggangu ketertiban umum. Dalam kaitan hal itu terdapat sebuah hadits yang menjelaskannya, yaitu:

${ }_{98}$ Muslim, Shahih Muslim, edisi Imam Nawawi (Beirut: Dar al Fikr, 1972), V: 156. Hadits dari Ziyad Ibn Ayyub, dari Abu Hurairah, h. 76.

99 Syamsul Anwar, Hukum Perjanjian Syariah..., h. 204. 


$$
\begin{aligned}
& \text { عن أ بي مسعود الانصاريّ انّ رسول الله صلّى الله عليه وسلّم نهى عن ثمن الكلب و }
\end{aligned}
$$

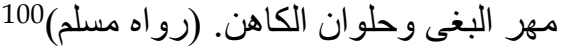

Hadits tersebut menggambarkan bahwasannya ketika sebuah objek itu merupakan sesuatu yang mengganggu ketertiban umum, maka terdapat larangan didalamnya untuk dijadikan objek.

Objek dari hipnoterapi sendiri adalah berupa perbuatan yang dapat diambil manfaatnya dan itu hanya dapat dilaksanakan oleh para ahli hipnoterapi yang sudah mendapat pelatihan intensif untuk bisa melaksanakan atau mempraktikkannya serta sudah bersertifikat. Objek tersebut pun dapat dijelaskan secara ilmiah karena merupakan bagian dari ilmu psikologi. Secara garis besar hipnoterapis memanfaatkan konsentrasi dan alam bawah sadar dari klien untuk mengikuti perkataannya agar dapat merubah persepsi mengenai permasalahan yang klien miliki. Objeknya pun sudah dijelaskan sebelum pelaksanaan hipnoterapi dan tidak ada paksaan sedikit pun untuk melanjutkan atau tidak. Selain itu, sifat atau hakikat dari objek ini memungkinkan untuk ditransaksikan dan tidak bertentangan syarak dan ketertiban umum. Hal itu terlihat ketika terdapat perintah untuk berdzikir sambil menutup mata dan menghantarkan pada setiap tahapan proses hipnoterapi.

Anggapan sebagian orang tentang hipnoterapi yang bisa mendatangkan ruh orang yang sudah meninggal sebagaimana contoh kasus yang ada pada bab sebelumnya adalah anggapan yang salah. Hal itu dikarenakan, hipnoterapi sama sekali tidak memanggil ruh itu untuk datang, melainkan hanya pendeskripsian kata-kata, kemudian klien-lah yang menggunakan imajinasinya menggambarkan sosok itu sampai ada dihadapannya.

4. Tujuan Akad

Tujuan akad adalah mewujudkan akibat hukum yang pokok dari akad. ${ }^{101}$ Misalnya tujuan akad jual beli adalah memindahkan hak milik atas barang dengan imbalan, tujuan akad sewa-menyewa adalah memindahkan milik atas manfaat barang yang disewa kepada penyewa dengan imbalan dan lain-lain.

Pencantuman kata-kata yang "sesuai dengan kehendak syariat" maksudnya adalah bahwa seluruh perikatan yang dilakukan oleh dua pihak atau lebih, tidak dianggap sah apabila tidak sejalan dengan syara'. Perjanjian harus merupakan perjanjian kedua belah pihak yang bertujuan untuk saling

100 Imam Muslim, Terjemah Hadis Shahih Muslim, terj. H.A Razak dan H. Rais Lathief, (Jakarta: Penerbit Pustaka Al-Husna, 1980), h. 256.

101 Syamsul Anwar, Hukum Perjanjian Syariah..., h. 218. 
mengikatkan diri tentang perbuatan yang akan dilakukan dalam suatu hal yang khusus setelah akad secara efektif mulai diberlakukan. ${ }^{102}$

Dari penjelasan tersebut, maka didapati bahwa tujuan akad hipnoterapi tak lain adalah untuk mempermudah pelaksanaan hipnoterapi. Sehingga, perikatan atau akad tersebut mempunyai tujuan yang tidak mengarah pelanggaran syara'.

\section{Kesimpulan}

Dari uraian tersebut, maka dapat ditarik kesimpulan bahwasanya Hipnoterapi pada PPT di wilayah Yogyakarta bukan termasuk pekerjaan yang dilarang oleh Islam. Hipnoterapi bisa diterapkan kepada siapa pun selama bisa mengerti bahasa yang disampaikan hipnoterapis. Karena kekuatan utama hipnoterapis adalah pada komunikasi, yang mana membutuhkan pemahaman dari klien. Setelah ditelusuri lebih lanjut, hipnoterapi di sebagain PPT di wilayah Yogyakarta, disertai nilai-nilai Islami dalam praktek kerjanya. Artinya praktek kerja tersebut tidak mengarah kepada kemusyrikan yang sangat dilarang oleh Islam. Terbukti ketika dalam prosesnya terdapat perintah berdzikir untuk mempermudah tahapan hipnoterapi. Selain itu, ketika dalam prosesnya ternyata klien membutuhkan penyembuhan dengan menghadirkan sosok seseorang yang sudah tiada, maka hipnoterapi bukan menghadirkan ruh dari seseorang tersebut, melainkan hanya mengarahkan dengan kata-kata kepada klien, kemudian klien-lah yang mendeskripsikan sendiri mengenai sosok tersebut. Karena secara nyata, hipnoterapis tidak mengetahui orang yang dimaksudkan dari klien. Manfaat yang didapat melalui hipnoterapi cukup efektif mengatasi permasalahan dari klien. Namun, efektifitasnya bersifat relatif. Maksudnya adalah semua tergantung dari kliennya dalam menjalani hipnoterapi. Laiknya seorang dosen yang memberikan kuliah kepada mahasiswa, bila klien dapat mengikuti secara baik, maka efek yang diterima cukup baik juga. Akad yang terjadi dalam hipnoterapi lebih bersifat mempermudah proses. Kesepakatan yang terjadi akan menjadi gerbang masuk untuk hipnoterapi dapat terlaksana. Karena kerelaan dengan tanpa paksaan menjadi tolak ukur untuk memasuki proses hipnoterapi. Syarat keabsahan dari kesepakatan untuk melakukan hipnoterapi yang diterapkan klinik / PPT di wilayah Yogyakarta terpenuhi dengan baik. Sehingga, untuk akad hipnoterapi yang terdapat di klinik / PPT di wilayah Yogyakarta bisa dikatakan tidak melanggar ketentuan hukum Islam.

102 Abdul Ghofur Anshori, Hukum Perjanjian Islam di Indonesia (Konsep, Regulasi, dan Implementasi), (Yogyakarta: Gajah Mada University Press 2010), h. 23. 


\section{Referensi}

Amrullah, M. Kholis, and M. Irfan Islamy. Perencanaan Penelitian: Perjalanan Sistematis Penemuan Teori. Edited by Ani Cahyadi. Malang: CV. Literasi Nusantara Abadi, 2020.

Anshori, Abdul Ghofur, Hukum Perjanjian Islam di Indonesia (Konsep, Regulasi, dan Implementasi), Yogyakarta: Gajah Mada University Press, 2010.

Anwar, Syamsul, Hukum Perjanjian Syariah: Studi tentang Teori Akad dalam Fikih Muamalat, Jakarta: PT Raja Grafindo Persada, 2010.

Basyir, Ahmad Azhar, Qa'idah-qa'idah Fiqih (Qawa'idul Fiqhiyah), Jakarta: Bulan Bintang, 1976.

Bungin, Burhan, Penelitian Kualitatif, Jakarta: Kencana Prenada Media Group, 2008.

Chaplin, James P., Kamus Lengkap Psikologi, terj. Kartini Kartono, Jakarta: PT Raja Grafindo Persada, 2006.

Departemen Agama RI, Al-Qur'an dan Terjemahnya, Bandung: CV Penerbit Diponegoro, 2000.

DEPDIKBUD Indonesia, Kamus Besar Bahasa Indonesia, Jakarta: Balai Pustaka, 2005.

Djuwaini, Dimyauddin, Pengantar Figh Muamalah, cet ke-2, Yogyakarta: Pustaka Pelajar, 2010.

Elias, Jack, Hipnotis \& Hipnoterapi Transpersonal/NLP, Yogyakarta: Pustaka Pelajar, 2009.

Ghazaly, Abdul Rahman dkk., Figh Muamalat, Jakarta: Kencana, 2010.

Hajar, Ibnu, Hypnoteaching, Yogyakarta: Diva Press, 2011.

Moleong, Lexy, Metodologi Penelitian Kualitatif, Bandung: PT. Remaja Rosda Karya, 2002.

Muslim, Shahih Muslim, edisi Imam Nawawi, Beirut: Dar al Fikr, 1972.

- - - -, Terjemah Hadis Shahih Muslim, terj. H.A Razak dan H. Rais Lathief, Jakarta: Penerbit Pustaka Al-Husna, 1980.

Nasa'i, Ahmad In Syu'aib Abu 'Abd ar-Rahman, Sunan an-Nasa'i (al-Mujtaba), edisi Jalaluddin al-Suyuti, Beirut: Dar al Kutub al 'Ilmiyyah, 1348.

Pasaribu, Chairuman dkk., Hukum Perjanjian dalam Islam, Jakarta: Sinar Grafika, 1996.

Rivai, Veithzal dkk., Islamic Transaction Law in Business: dari Teori ke Praktik, Jakarta: Bumi Aksara, 2011.

Sugiyono, Metode Penelitian Bisnis, Bandung: CV Alfabeta, 2007.

Zuhaili, Wahbah az-, al-Figh al-Islami wa Adillatuh, cet. ke-3, Damaskus:Dar alFikr, 1989. 